\title{
Kinerja Perusahaan Ditinjau Dari Faktor Non Keuangan Dan Struktur Modal
}

\author{
Diyan Lestari dan Bambang Wahyudi Wicaksono \\ Fakultas Bisnis, Institut Teknologi dan Bisnis Kalbis dan Fakultas Ekonomi, \\ Institut Bisnis Nusantara \\ diyan.lestari@kalbis.ac.iddan bambang.ww@ibn.ac.id
}

\begin{abstract}
This study aims to analyze the performance of food and beverage companies listed on the Indonesia Stock Exchange from the period 2009 to 2016, in terms of nonfinancial factors consisting of corporate governance as measured by Board Size, Independent Board of Commissioners, Audit Committee, and Concentrated Ownership. Other non-financial factors are innovation which is one of the supporting factors to improve performance. Capital structure plays an important role in improving organizational performance. To analyze the effect on organizational performance in terms of non-financial factors and capital structure, this study uses multiple linear regression with panel data. The results of this study indicate that the Board Size.
\end{abstract}

Keywords: Board Size, Independent Board of Commissioners, Audit Committee, Concentrated Ownership, Innovation, Capital Structure, Performance

\begin{abstract}
Abstrak: Penelitian ini bertujuan untuk menganalisa mengenai kinerja perusahaan makanan dan minuman yang terdaftar di Bursa Efek Indonesia dari periode tahun 2009 sampai dengan tahun 2016, ditinjau dari faktor non keuangan yang terdiri dari corporate governance yang diukur dengan Board Size, Dewan Komisaris Independen, Komite Audit, dan Kepemilikan Terkonsentrasi. Faktor non keuangan lainnya adalah inovasi yang merupakan salah satu faktor penunjang untuk meningkatkan kinerja. Struktur modal berperan penting dalam meningkatkan kinerja organisasi. Untuk menganalisa pengaruh pada kinerja organisasi yang ditinjau dari faktor non keuangan dan struktur modal, penelitian ini menggunakan regresi linear berganda dengan data panel. Hasil penelitian ini menunjukkan bahwa Board Size .
\end{abstract}

Kata kunci: Board Size, Dewan Komisaris Independen, Komite Audit, Kepemilikan Terkonsentrasi, Inovasi, Struktur Modal, Kinerja

\section{PENDAHULUAN}

Pertumbuhan ekonomi Indonesia berkembang cukup baik terutama setelah adanya krisis ekonomi di tahun 1997/ 1998. LPEM FEB UI (2018) memproyeksikan pertumbuhan GDP mengalami sedikit peningkatan dari 5.2\% di tahun 2017 menjadi 5.3\% di tahun 2018. Selain itu, sektor manufaktur tumbuh di bawah GDP di tahun 2018, sementara sektor jasa bertumbuh lebih cepat dibandingkan pertumbuhan GDP. Pertumbuhan konsumsi masih lemah. Akan tetapi, sektor manufaktur masih memberikan kontribusi yang cukup besar bagi penyerapan tenaga kerja di Indonesia. Kemenperin memproyeksikan jumlah tenaga kerja yang dapat diserap oleh sektor manufaktur sebesar 
17,01 juta orang di tahun 2017 (Faizal, 2017). Akan tetapi, di tengah menurunnya pertumbuhan sektor manufaktur, laju pertumbuhan pendapatan dari sektor consumer goods relatif lebih cepat dibandingkan dengan negara-negara lainnya di Asia Tenggara dan memiliki growth sebesar $8.3 \%$, tertinggi dibandingkan dengan dengan negara Asia Tenggara yang lain dan jauh lebih tinggi dibandingkan dengan tahun lalu (Widianto, 2017). Pertumbuhan ekonomi suatu negara tentunya harus diimbangi dengan pertumbuhan kinerja sektor mikro yang ada di dalam negara tersebut. Sektor mikrolah yang nantinya akan menopang sektor makro.

Pada dasarnya, setiap perusahaan menginginkan kinerja yang terus meningkat. Berbagai upaya akan dilakukan agar terus bertumbuh. Berdasarkan berbagai studi, terdapat beberapa faktor yang berpengaruh terhadap kinerja perusahaan. Salah satu faktornya adalah inovasi. Inovasi merupakan proses kompleks terkait dengan perubahan pada fungsi produksi dan proses di mana perusahaan berusaha memperoleh dan membangun keunggulan kompetitifnya terkait dengan penggunaan teknologi, memahami berbagai sumber dayanya dan bagaimana perusahaan mentransformasinya melalui kemampuan yang memiliki nilai tambah (Therrien, Doloreux, \& Chamberlin, 2011). Perusahaan consumer goods, memiliki karakteristik yang cukup unik. Industri tersebut sangat erat kaitannya dengan inovasi produk, sebagai contoh di Amerika Serikat, sektor grocery memiliki SKU yang tumbuh rata-rata sekitar 50\% hanya dalam tujuh tahun terakhir (McKinsey\&Company, 2010).

Perusahaan-perusahaan consumer goods, pada dasarnya merupakan salah satu bagian dari industri manufaktur yang fokus dalam kegiatan penambahan nilai suatu produk, dan memberikan kontribusi yang cukup besar dalam penyerapan tenaga kerja. Pertumbuhan industri consumer goods pada YTD 2017 menunjukkan hanya bertumbuh sebesar $2.7 \%$ dengan rata-rata pertumbuhan sebesar $11 \%$, dan pada momentum Hari Raya Idul Fitri juga hanya dapat bertumbuh sebesar 5\%. Terdapat berbagai faktor yang menyebabkan adanya perlambatan tersebut, salah satunya adalah pendapatn masyarakat yang tidak mengalami peningkatan, juga pergeseran preferensi konsumen dari goods ke leisure activity (SBM BINUS, 2017). Akan tetapi, dengan adanya inovasi yang terusmenerus, diharapkan dapat mengatasi adanya kejenuhan masyarakat terhadap konsumsi produk dan akan berdampak pada peningkatan kinerja. Selain itu, pengelolaan perusahaan yang tepat juga akan berdampak pada kinerja perusahaan yang baik. Pertumbuhan industri makanan dan minuman terus meningkat mencapai 9.23\% di tahun 2017 dibandingkan tahun 2016 yang mencapai 8.46\%. Selain itu, sektor tersebut juga memberikan kontribusi yang cukup besar ke PDB non migas, yaitu sebesar 34.33\% (Yasmin, 2018).

Berdasarkan Tabel 1 mengenai Indonesia innovation index menunjukkan bahwa di tahun 2017, Indonesia memiliki peringkat inovasi relatif lebih tinggi dibandingkan tahun sebelumnya, hal tersebut juga diikuti dengan meningkatnya innovation index. Akan tetapi, indeks inovasi Indonesia secara rata-rata tidak jauh berbeda. Padahal, inovasi merupakan hal yang penting yang akan menopang pertumbuhan suatu negara, dan innovation index suatu negara merupakan akumulasi dari tingkat mikro. Atalay, Anafarta, \& Sarvan (2013), meneliti bahwa inovasi (inovasi produk dan proses) memiliki pengaruh positif terhadap kinerja perusahaan. Penelitian yang sama dilakukan oleh Tuan \& et al., (2016), menemukan bahwa inovasi proses, marketing, dan organisasi berpengaruh terhadap kinerja perusahaan, dan semakin tinggi kegiatan inovasi yang dilakukan, akan meningkatkan kinerja perusahaan. 
Tabel 1. Indonesia Innovation Index

\begin{tabular}{rrr}
\hline Date & Innovation Ranking & Innovation Index \\
\hline 2017 & $87^{\circ}$ & 30.1 \\
2016 & $88^{\circ}$ & 29.07 \\
2015 & $97^{\circ}$ & 29.79 \\
2014 & $87^{\circ}$ & 31.81 \\
2013 & $85^{\circ}$ & 31.95 \\
2012 & $100^{\circ}$ & 28.1 \\
2011 & $99^{\circ}$ & 27.78 \\
\hline
\end{tabular}

Sumber : countryeconomy.com

Beberapa studi menyebutkan bahwa corporate governance memiliki pengaruh yang signifikan terhadap kinerja perusahaan di tahun 1990an. Gompers, Ishii, \& Metrick (2003) menyebutkan bahwa tingkat pengembalian saham perusahaan dengan pemegang saham yang kuat memiliki kinerja yang lebih baik dibandingkan dengan perusahaan lainnya. Lestari (2018) menyebutkan bahwa corporate governance memerankan peranan penting untuk meningkatkan kinerja perusahaan, corporate governance juga akan memberikan kendali bagi manajemen untuk memilih proyek-proyek yang berisiko dan juga yang tidak berisiko. Di berbagai negara, kinerja perusahaan akan sangat menopang perekonomian. Penelitian yang dilakukan oleh Molnar, Chen, \& Wang (2017), menyebutkan bahwa prioritas utama di Cina, ketika negara tersebut mengalami pertumbuhan yang menurun, yang merupakan kondisi di mana tingkat pengembalian atas suatu investasi berkurang, adalah corporate governance. Corporate governance yang baik akan berdampak pada peningkatan produktivitas dengan adanya management sumber daya yang lebih baik.

Selain itu, struktur modal yang optimal juga merupakan salah satu komponen penting untuk menentukan kinerja suatu perusahaan. Struktur modal yang optimal merupakan struktur modal yang memiliki cost of capital yang lebih rendah dibandingkan dengan tingkat pengembaliannya. Perusahaan consumer goods, terutama perusahaan makanan dan minuman cukup aktif dalam melakukan ekspansi, terutama terkait dengan ketersediaan produk mereka di retail channel, agar memudahkan untuk dijangkau oleh konsumen. Oleh karena itu, sektor tersebut harus bijak dalam mengambil keputusan terkait dengan struktur modalnya. Ogebe, Ogebe, \& Alewi (2013) menyatakan bahwa pemilihan struktur modal yang optimal memberikan dampak pada kinerja perusahaan. Bui (2017) melakukan studi mengenai pengaruh financial leverage terhadap kinerja perusahaan dan menemukan bahwa perusahaan harus menerapkan struktur modal yang optimal dan mempertimbangkan biaya kebangkrutan dan biaya modal dalam perhitungannya.

\section{KAJIAN TEORI}

Agency Theory. Agency theory merupakan alat penting untuk menganalisa dan memahami skandal etik perusahaan. Konsep teori keagenan menunjukkan adanya isu mengenai pemisahan dan pengendalian, meneliti mengenai agency cost yang muncul karena adanya penggunaan utang dan ekuitas, menjelaskan mengenai penggunaan cost dan mengapa hal tersebut dilakukan (Jensen \& Meckling, 1976). Agency theory atau teori 
keagenan menjadi landasan adanya sebuah sistem yang disusun untuk melakukan pengendalian, Namazi (2013) menyebutkan bahwa sistem pengendalian manajemen yang paling sesuai mengindikasikan 2 hal penting, yitu 1). Strategic planning cycle, dan 2) control cycle.

Hubungan keagenan, pada dasarnya merupakan landasan terkait dengan hubungan antara principal dan agen yang masing-masing memilik conflict of interest. Konflik keagenan atau sering disebut sebagai agency conflict pada dasarnya fokus pada: 1). Kontrak yang optimal-terkait dengan perancangan kompensasi para manajemen untuk meningkatkan insentif para manajer dengan tujuan untuk menstimulus kinerja guna memaksimalkan shareholer value, 2). Pengaruh kontrak pada tindakan para manajer dikaitkan dengan insentif, yang dapat dilakukan dengan kepemilikan manajerial atau pembobotan pembayaran insentif berasarkan kinerja, yang dikaharpkan daat meningkatkan kinerja manajer, 3). Pengaruh tindakan manajer terhadap kinerja perusahaan (Bitler, Moskowitz, \& Jorgensen, 2006).

Resource Based View. Resource-Based View (RBV) merupakan teori yang mengasumsikan bahwa kestabilan produk akan menentukan nilai suatu sumber daya. $A$ Resource-Based View dimulai dengan pernyataan, bagi perusahaan, sumber daya dan produk merupakan hal yang penting. Resource-based view menyatakan bahwa perusahaan yang memiliki sumber daya melimpah akan mempermudah mereka memperoleh competitive advanatge dan memicu kinerja yang baik secara jangka panjang (Barney, 1991). Memahami keunggulan kompetitif sebuah perusahaan merupakan hal penting.

Resource based view menjadi landasan penting mengenai perumusan strategi yang tepat bagi perusahaan untuk memenangkan persaingan. Theriou, Aggelidis, \& Theriou (2009) melakukan studi mengenai perumusan strategi menggunakan pendekatan RBV dan KBV dan menemukan bahwa kedua pendeketan tersebut saling melengkapi. Pada Resource Based View Theory, menyatakan bahwa pada dasarnya sumber daya merupakan hal penting, berharga dan jarang, serta dapat memberikan sumbangsih penting bagi kelangsungan perusahaan dan menciptakan keunggulan kompetitif. Keunggulan kompetitif tersebut dapat bertahan lama jika perusahaan mampu melindungi sumber dayanya, mengurangi adanya pemalsuan, maupun adanya substitusi dari perusahaan pesaing (Wade \& Hulland, 2004).

Corporate Governance. Corporate Governance, atau sering disebut sebagai tata kelola merupakan hubungan antara manajemen perusahaan, Board of Director, pemegang sahamnya, dan juga para stakeholder lainnya. Corporate governance memberikan struktur tentang bagaimana perusahaan mencapai tujuannya, dan juga melakukan monitoring kinerja yang ditentukan. Corporate governance yang buruk diidentifikasi sebagai salah satu penyebab utama krisis ekonomi pada tahun 1997/ 1998 yang terjadi di Indonesia. Setelah krisis tersebut, mulailah disusun berbagai regulasi dan menetapkan berbagai standar untuk membantu perusahaan melakukan pengelolaan lebih baik (OECD, 2015). Kualitas tata kelola atau corporate governance akan mempengaruhi kinerja perusahaan, karena terkait dengan berbagai aspek penting mulai dari perencanaan, eksekusi, dan evaluasi atau monitoring strategi perusahaan. Corporate Governance, dapat diidentifikasi melalui para direkturnya (Board Size), Dewan Komisaris Independen, Komite Audit, dan Kepemilikan Terkonsentrasi. 
Berbagai studi mengenai corporate governance menunjukkan bahwa corporate governance berpengaruh terhadap kinerja perusahaan. Istilah corporate governance pada dasarnya menjelaskan mengenai bagaimana perusahaan diarahkan dan dikendalikan. Keseluruhan tujuan dari adanya corporate governance pada dasarnya adalah untuk memastikan adanya pertumbuhan yang berkelanjutan atau perusahaan dapat bertahan dan mencapai berbagai tujuannya (Mohamed, Basuony, \& Badawi, 2013). Penelitian yang dilakukan oleh Sueyoshi, Goto, \& Omi (2010) menyatakan bahwa perusahaan-perusahaan di Jepang cukup khawatir dengan adanya investasi asing. Akan tetapi, berdasarkan hasil studi, kepemilikan asing akan meningkatkan kinerja perusahaan. Untuk itu, perusahaan perlu melakukan evaluasi terhadap strategi tata kelola perusahaannya.

H1 : Board Size berpengaruh terhadap kinerja perusahaan

H2 : Dewan Komisaris Independen berpengaruh terhadap kinerja perusahaan

H3 : Komite Audit berpengaruh terhadap kinerja perusahaan

H4 : Kepemilikan Terkonsentrasi berpengaruh terhadap kinerja perusahaan

Inovasi. Inovasi merupakan kegiatan pembuatan produk baru maupun penambahan sesuatu yang baru pada produk yang sudah ada. Berbagai studi dan fenomena menyebutkan bahwa inovasi merupakan hal penting dan harus dilakukan oleh setiap individu dan organisasi untuk tetap bertahan dan terus bertumbuh. Perusahaan harus berinovasi, karena jika hal tersebut tidak dilakukan, maka akan tergeser dengan perusahaan lainnya yang dapat memenuhi kebutuhan konsumen yang cukup dinamis. Inovasi dapat didefinisikan sebagai suatu produk baru atau penambahan pada produk yang sudah ada, penggunaan proses industri yang baru, pembukaan pasar baru, pengembangan sumber bahan baku baru atau berbagai input baru, dan bentuk organisasi yang baru (Vyas, 2009). Sedangkan perusahaan yang inovatif adalah perusahaan yang melakukan kegiatan investasi pada kegiatan inovasi dan memiliki dampak positif dan juga berdampak pada tingkat penjualan yang positif.

Berbagai fenomena yang ada menunjukkan bahwa sebuah perusahaan dapat melakukan analisa SWOT untuk merumuskan strategi inovasinya untuk menggali keunggulan kompetitifnya dan dapat bersaing dengan perusahaan yang lain (Karabulut, 2015). Atalay, Anafarta, \& Sarvan (2013) menyatakan bahwa inovasi pada dasarnya merupakan sumber daya yang penting untuk mencapai keunggulan kompetitif yang dapat berlangsung seterusnya pada lingkungan yang terus mengalami perubahan. Kegiatan inovasi yang tepat dapat memicu adanya peningkatan pada produk dan proses aktivitas, serta improvement yang dapat membantu perusahaan bertahan, tumbuh lebih cepat, menjadi lebih efisien, dan lebih menguntungkan dibandingkan perusahaan yang cenderung tidak inovatif.

H5 : Inovasi berpengaruh terhadap kinerja perusahaan

Struktur Modal. Struktur modal merupakan salah satu faktor yang penting untuk meningkatkan kinerja sebuah perusahaan. Kebijakan mengenai struktur modal merupakan hal penting, mengingat terdapat berbagai pilihan yang dapat dipertimbangkan oleh perusahaan untuk memperoleh tingkat pengembalian yang maksimal. Struktur modal yang optimal adalah struktur modal yang memiliki tingkat pengembalian yang lebih besar dibandingkan dengan cost of capitalnya. Berdasarkan pecking order theory, perusahaan akan memilih sumber dana dari internal terlebih dahulu, kemudian eksternal. Dana eksternal dapat diperoleh dari utang, maupun menerbitkan ekuitas. Studi mengenai struktur modal merupakan hal yang cukup menarik di kalangan akademisi dan praktisi. 
Berdasarkan studi yang dilakukan oleh Salim \& Yadav (2012), struktur modal memiliki pengaruh negatif terhadap kinerja perusahaan.

Pengendalian penggunaan utang juga merupakan hal penting yang perlu diperhatikan dalam kebijakan pendanaan suatu perusahaan. Terdapat indikasi bahwa penggunaan utang akan berpengaruh negatif terhadap kinerja perusahaan, terutama di negara berkembang seperti Vietnam, manfaat pengurangan pajak yang ada belum dapat dirasakan dan dampak terhadap distress jauh lebih besar dibandingkan dengan manfaat yang diperoleh (Le \& Phan, 2017). Begitu pula studi yang dilakukan oleh Ramadan \& Ramadan (2015) yang menyatakan bahwa terdapat pengaruh negatif antara struktur modal terhadap kinerja perusahaan di Yordania. Sehingga perusahaan harus menetapkan kebijakan struktur modal mereka dengan hati-hati.

H6 : Struktur modal berpengaruh terhadap kinerja perusahaan.

\section{METODE}

Populasi dalam penelitian ini adalah perusahaan food and beverages (makanan dan minuman) yang terdaftar di Bursa Efek Indonesia pada tahun 2009 sampai dengan tahun 2016. Teknik sampling yang digunakan dalam penelitian ini adalah pusposive sampling, yang dapat diartikan bahwa dalam menentukan sampel, menggunakan kriteria-kriteria tertentu. Kriteria dalam penelitian ini adalah sebagai berikut: (1) Perusahaan makanan dan minuman yang terdaftar pada Bursa Efek Indonesia dari tahun 2009 sampai dengan tahun 2016; (2) Perusahaan memiliki laporan keuangan yang lengkap; (3) Tidak pernah delisting dari Bursa selama periode pengamatan.

Penelitian ini terdiri dari 10 perusahaan makanan dan minuman atau food and baverages. Data yang digunakan adalah data sekunder yang bersumber dari Bursa Efek Indonesia. Regresi linear berganda dengan data panel digunakan untuk mengkaji permasalahan mengenai kinerja perusahaan yang ditinjau dari strategi inovasi, corporate governance, dan struktur modal. Regresi linear berganda dengan data panel dipilih karena menggunakan data yang menggabungkan antara data cross section dan time series.

Operasionalisasi dan Pengukuran Variabel. Variabel Dependen. Kinerja Perusahaan Kinerja perusahaan diukur dengan menggunakan perbandingan antara net income dan total equity (Brigham \& Houston, 2006).

Independent Variables. Variabel independen dalam penelitian ini meliputi corporate governance dengan indikator Board Size yang diukur dengan menggunakan jumlah board of director dalam suatu perusahaan (Horváth \& Spirollari, 2012), Komite Audit diukur dengan menggunakan variabel dummy dengan nilai 1 jika perusahaan menggunakan perusahaan auditor yang termasuk dalam The Big Four Auditors (Shamsabadi, Min, \& Chung, 2016), Dewan Komisaris Independen diukur dengan menggunakan jumlah komisaris independen yang ada dalam suatu perusahaan (Horváth \& Spirollari, 2012), Kepemilikan Terkonsetrasi diukur menggunakan persentase kepemilikan terbesar dalam perusahaan (Nguyen, Locke, \& Reddy, 2015), Strategi Inovasi diukur dengan menggunakan perbandingan antara research and development expenditure dengan total penjualan (Ezzi \& Jarboui, 2016), dan Struktur Modal yang diukur dengan membandingkan antara total utang dibandingkan dengan total ekuitasnya (Brigham \& Houston, 2006). 
Control Variables. Size sebagai karakteristik perusahaan diukur dengan log dari total asset.

Teknik Pengumpulan Data. Penelitian ini menggunakan data sekunder dengan tipe data panel yang memiliki karakteristik gabungan antara data cross section dan time series. Pengumbpulan data dalam penelitian ini menggunakan laporan keuangan perusahaanperusahaan go public yang terdaftar di Bursa Efek Indonesia.

\section{HASIL DAN PEMBAHASAN}

Perusahaan-perusahaan yang diteliti dalam penelitian ini adalah perusahaan makanan dan minuman yang terdaftar di Bursa Efek Indonesia, dengan jumlah perusahaan sebanyak 10 perusahaan yang dijadikan sampel, antara lain: PT Akasha Wira International, Tiga Pilar Sejahtera Food, Cahaya Kalbar, Delta Djakarta, Indofood Sukses Makmur, Multi Bintang Indonesia, Mayora Indah, Prashida Aneka Niaga, Siantar Top, dan Ultrajaya Milk Industry \& Trading Company. Sebelum melakukan pembahasan lebih lanjut, untuk mengetahui karakteristik data penelitian, sangat perlu dilakukan pembahasan mengenai statistik deskriptif yang ditunjukkan oleh Tabel 1.

Tabel 1. Statistik Deskriptif

\begin{tabular}{lrrrrr}
\hline \multicolumn{1}{c}{ Variables } & Mean & Max & Min & Std. Dev & Obs \\
\hline Keputusan Investasi & & & & & \\
Kinerja Perusahaan & 0.279763 & 3.236 & -0.131 & 0.446265 & 80 \\
& & & & & \\
Variabel Independen & & & & & \\
Board & 4.525 & 12 & 2 & 2.158146 & 80 \\
Dki & 1.7 & 4 & 0 & 0.86273 & 80 \\
Audit & 0.525 & 1 & 0 & 0.502525 & 80 \\
Own & 0.543553 & 0.9194 & 0.1438 & 0.244274 & 80 \\
Lev & 1.1305 & 8.44 & 0.18 & 1.012016 & 80 \\
Inov & 0.016263 & 0.165 & 0.001 & 0.034232 & 80 \\
Size & 12.33346 & 13.963 & 11.251 & 0.641298 & 80 \\
\hline
\end{tabular}

Sumber: data hasil penelitian (diolah)

Tabel 1 menjelaskan mengenai statistik deskriptif penelitian. Berdasarkan data tersebut, menunjukkan bahwa kinerja perusahaan memiliki nilai mean sebesar 0.279763, nilai maximum sebesar 3.236, nilai minimum sebesar -0.131 , dan nilai standar deviasi sebesar 0.446265. Sedangkan board size memiliki nilai mean sebesar 4.525, nilai maximum sebesar 12, nilai minimum sebesar 2 dan standar deviasi sebesar 2.158146. Dewan komisaris independen memiliki nilai mean sebesar 1.7, nilai maximum sebesar 4, nilai minimum sebesar 0, dan standar deviasi sebesar 0.86273 .

Kepemilikan terkonsentrasi memiliki nilai mean sebesar 0.543553 , nilai maximum sebesar 0.9194, nilai minimum sebesar 0,1438, dan standar deviasi sebesar 0.244274. Sedangkan strategi inovasi memiliki nilai mean sebesar 0.016263, nilai maximum sebesar 
0.165 , nilai minimum sebesar 0.001 , dan standar deviasi sebesar 0.034232. Struktur modal memiliki nilai mean sebesar 1.1305 , nili maximum sebesar 8.44 , nilai minimum sebesar 0.18 dan standar deviasi sebesar 1.012016. Sedangkan ukuran perusahaan memiliki nilai mean sebesar 12.33346, nilai maximum sebesar 13.963, nilai minium sebesar 11.251, dan standar deviasi sebesar 0.641298 .

Uji Multikolinearitas. Uji multikolinearitas digunakan untuk mengetahui apakah terdapat gejala multikolinearitas atau tidak pada model regresi. Jika terdapat multikolinearitas, maka terdapat indikasi bahwa hasil pengujian dapat menjadi bias. Dalam penelitian ini menggunakan matriks korelasi untuk melihat apakah model mengalami gejala multikolinearitas. Tabel 2 menjelaskan mengenai Uji Multikolinearitas dengan menggunakan matriks korelasi. Berdasarkan data tersebut, dapat dilihat bahwa model tidak mengelami gejala multikolinearitas karena hasil statistik menunjukkan angka di bawah 0.8 .

Tabel 2. Correlation Matrix

\begin{tabular}{lrrrrrrr}
\hline Variables & \multicolumn{1}{l}{ BOARD } & \multicolumn{1}{c}{ DKI } & \multicolumn{1}{c}{ AUDIT } & OWN & LEV & INOV & SIZE \\
\hline BOARD & 1 & & & & & & \\
DKI & 0.588755 & 1 & & & & & \\
AUDIT & 0.466284 & 0.572263 & 1 & & & & \\
OWN & -0.08274 & -0.02131 & 0.36 & 1 & & & \\
LEV & -0.03918 & 0.225909 & 0.104514 & 0.194122 & 1 & & \\
INOV & -0.13194 & -0.07102 & -0.07102 & 0.407824 & 0.032519 & 1 & \\
SIZE & 0.675036 & 0.492542 & 0.492542 & -0.45009 & 0.019482 & -0.25366 & 1 \\
\hline
\end{tabular}

Sumber: data hasil penelitian (diolah)

Penelitian ini dianalisis menggunakan regresi berganda dengan data panel yang diolah dengan menggunakan software Eviews. Tabel 3 menunjukkan hasil analisis regresi. Kolom pertama merupakan hasil regresi linear berganda dengan data panel dengan menggunakan common effect, sedangkan kolom kedua merupakan pengujian dengan menggunakan fixed effect, dan kolom ketiga merupakan hasil regresi dengan menggunakan random effect.

Table 3. Kinerja Perusahaan

\begin{tabular}{lrrrrrr}
\hline & \multicolumn{7}{c}{ Dependent variable: PERFORM } \\
& Coeff & \multicolumn{1}{c}{1} & Coeff & \multicolumn{1}{c}{2} & Coeff & \multicolumn{1}{c}{3} \\
\hline $\begin{array}{l}\text { Explanatory } \\
\text { variables }\end{array}$ & & & & & & \\
BOARD & -0.08826 & 0.0005 & 0.008256 & 0.7699 & -0.00057 & $0.0484^{*}$ \\
DKI & 0.008461 & 0.8798 & -0.06301 & 0.1413 & -0.06373 & $0.0985^{* *}$ \\
AUDIT & 0.313368 & 0.0044 & 0.217195 & 0.0992 & 0.198693 & $0.0906^{* *}$ \\
OWN & 0.146862 & 0.4094 & 0.206563 & 0.8243 & -0.0071 & 0.5327 \\
INOV & 0.843395 & 0.4504 & -0.4646 & 0.5315 & -0.02751 & 0.6202 \\
LEV & 0.301415 & 0 & 0.260932 & 0 & -0.00143 & 0 \\
SIZE & 0.150692 & 0.0827 & 0.103659 & 0.3505 & 0.019433 & 0.3684 \\
Observations & & 80 & & 80 & & 80
\end{tabular}


Number of Companies

10

0.68641

0.655922

Adjusted R-squared

Chow Test

Hausman Test
10

0.922843

0.903247

0
10

0.737211

0.711662

0.9541

*significant pada level 5\%

**significant pada level $10 \%$

Tabel 3 menunjukkan hasil pengujian regresi berganda dengan data panel. Sebelum melakukan pembahasan lebih jauh, terlebih dahulu dilakukan uji kelayakan model untuk menentukan model regresi yang paling sesuai antara common effect, fixed effect, dan random effect. Chow Test merupakan pengujian untuk memilih model yang paling sesuai antara common effect dan fixed effect. Berdasarkan hasil uji, Chow Test menunjukkan nilai di bawah 5\%, sehingga model yang sesuai adalah fixed effect. Sedangkan Hausman Test menguji kesesuaian model antara fixed effect dan random effect. Berdasarkan hasil uji, Hausman Test menunjukkan nilai sebesar 0.9541 yang berarti di atas 5\%, sehingga model yang sesuai adalah random effect. Berdasarkan kriteria tersebut, maka model yang dipilih adalah random effect.

Hasil uji regresi berganda yang ditunjukkan pada Tabel 3 menjelaskan pengaruh variabel independen terhadap variabel dependen. Variabel Board Size memiliki koefisien negatif, yaitu -0.08826 dan berpengaruh pada level signifikansi 5\%. Hal tersebut menggambarkan bahwa semakin tinggi jumlah direktur, akan berdampak negatif terhadap kinerja perusahaan. Seorang direktur pada dasarnya memiliki tugas yang salah satunya adalah memimpin perusahaan, dan melakukan pengawasan terhadap para karyawannya. Pengawasan dan komunikasi yang tidak efektif serta dampak birokrasi yang ditimbulkan dengan adanya jumlah direktur yang bertambah dapat memperburuk kinerja perusahaan. Hal tersebut konsisten dengan penelitian yang dilakukan oleh Arosa, Iturralde, \& Maseda (2013) yang menyatakan bahwa jumlah direktur berpengaruh negatif terhadap kinerja perusahaan. Pengaruh negatif mengindikasikan bahwa terdapat koordinasi yang buruk, kurangnya fleksibilitas, dan komunikasi yang buruk dalam direktur dengan jumlah yang lebih besar dibandingkan manfaat yang diperoleh dengan adanya pengendalian aktivitas para manajer oleh direktur. Bennedsen, Kongsted, \& Nielsen (2008), menyatakan bahwa pemilihan jumlah direktur yang optimal merupakan trade-off antara manfaat yang diperoleh melalui berbagai kompetensi dan cost yang muncul dengan adanya free-riding antara para direktur.

Dewan Komisaris Independen memiliki pengaruh terhadap kinerja perusahaan pada tingkat signifikansi $10 \%$. Dewan Komisaris Independen pada dasarnya merupakan Dewan Komisaris yang tidak memiliki keterkaitan atau hubungan dengan manajemen, pemegang saham, hubungan keluarga dengan Dewan Komisaris yang lain, dan hubungan terkait dengan masalah keuangan, serta hubungan lain yang dapat mempengaruhi kemampuannya untuk bertindak secara independen. Berdasarkan hasil uji regresi, maka dengan adanya Dewan Komisaris Independen dapat meningkatkan kinerja perusahaan. Independensi sangat penting untuk diperhatikan karena dapat berimbas pada perumusan kebijakan, yang pada akhirnya akan berdampak pada kinerja perusahaan. Hal tersebut erat kaitannya dengan transparansi dan objektifitas dalam merumuskan kebijakan dan 
pengambilan keputusan, sehingga diharapkan dapat membantu perusahaan dalam membuat kebijakan yang objektif. Hasil penelitian yang dilakukan oleh Barani, Garkaz, \& Pazkad (2013), Dewan Komisaris independen berpengaruh positif terhadap kinerja perusahaan.

Komite Audit berpengaruh positif terhadap kinerja perusahaan pada tingkat signifikansi $10 \%$. Komite audit dicerminkan dengan adanya perusahaan auditor yang termasuk dalam The Big Four Auditors. Hasil tersebut mengindikasikan bahwa dengan adanya perusahaan audit yang memiliki kredibilitas tinggi, diharapkan mampu melakukan pengendalian dan menerapkan sistem yang lebih baik dibandingkan dengan perusahaan auditor lainnya. Perusahaan auditor yang memiliki pengalaman dan kinerja yang sudah terbukti akan diasosiasikan dengan kinerja yang positif pada perusahaan yang ditangani (Aldamen \& et. al., 2012). Kallamu \& Saat (2015) juga menyatakan bahwa adanya audior yang independen akan membantu perusahaan melakukan analisa terhadap kondisi perusahaan dengan lebih objektif sehingga membantu meningkatkan kinerja perusahaan.

Berdasarkan hasil pengujian pada tabel 3, menunjukkan bahwa kepemilikan terkonsentrasi tidak berpengaruh terhadap kinerja perusahaan. Kepemilikan terkonsentrasi pada dasarnya mencerminkan persentase kepemilikan terbesar dalam suatu perusahaan. Semakin tinggi kepemilikan terkonsentrasi mengindikasikan adanya pengendalian yang semakin tinggi pula oleh sekelompok pemegang saham. Sehingga, hal tersebut akan mengurangi objektifitas dalam melakukan analisa dan pengendalian kinerja. Kepemilikan manajerial dapat menjadi alternatif untuk mengurangi tingkat konsentrasi kepemilikan yang ada di sebuah perusahaan. Sebaiknya tingkat kepemilikan dalam suatu perusahaan dijaga secara optimal untuk memudahkan pengendalian dan pengambilan kebijakan (Grosfeld, 2011).

Kinerja suatu perusahaan juga ditentukan dari bagaimana perusahaan tersebut dapat bersaing dengan perusahaan lain. Di tengah persaingan yang ketat, perusahaan diwajibkan untuk selalu berinovasi. Dalam penelitian ini, inovasi tidak berpengaruh terhadap kinerja perusahaan yang mengindikasikan adanya tingkat kebutuhan kegiatan inovasi pada perusahaan makanan dan minuman yang pada dasarnya cukup inovatif dan masih diperlukan lagi aktivitas inovasi yang superior sehingga berdampak terhadap kinerja perusahaan. Struktur modal berpengaruh terhadap kinerja perusahaan pada level $5 \%$. Koefisien regresi menunjukkan struktur modal berpengaruh positif terhadap kinerja perusahaan, yang mengindikasikan bahwa semakin optimal kebijakan struktur modal yang ditetapkan oleh perusahaan, maka akan mendorong kinerja perusahaan menjadi lebih baik. Ilyukhin (2015) menyatakan bahwa penggunaan struktur modal, khususnya terkait dengan penggunaan utang dapat berdampak positif terhadap kinerja perusahaan karena utang dapat menjadi alat untuk mendisiplinkan manajemen.

\section{PENUTUP}

Simpulan. Penelitian ini mengkaji mengenai faktor-faktor non keuangan terhadap kinerja perusahaan yang terdiri dari corporate governance dengan menggunakan indikator Board Size, Dewan Komisaris Independen, Komite Audit, dan Kepemilikan Terkonsentrasi. Faktor non keuangan lainnya adalah inovasi yang berperan penting untuk meningkatkan keunggulan kompetitif dan memenangkan persaingan bisnis. Selain itu penelitian ini juga melakukan analisa mengenai kebijakan pendanaan terkait dengan kebijakan struktur modal perusahaan. Hasil penelitian menunjukkan bahwa Board Size berpengaruh negatif 
terhadap kinerja perusahaan, sedangkan Dewan Komisaris Independen dan Komite Audit berpengaruh positif terhadap kinerja perusahaan. Kepemilikan terkonsentrasi tidak berpengaruh terhadap kinerja perusahaan. Hal tersebut mengimplikasikan bahwa jumlah direktur dalam sebuah perusahaan harus optimal karena terkait dengan perumusan kebijakan, komunikasi, dan birokrasi perusahaan sehingga terselenggara sistem yang efektif dan efisien.

Dewan Komisaris Independen berpengaruh positif menunjukkan bahwa adanya pengendalian, independensi, dan transparansi akan membantu perusahaan untuk lebih objektif dalam merumuskan kebijakan yang diharapkan akan berdampak baik terhadap kinerja. Komite Audit dalam penelitian ini diukur dengan perusahaan auditor yang termasuk ke dalam the big four auditor. Dalam penelitian ini, terdapat pengaruh positif antara komite audit dengan kinerja perusahaan. Dengan adanya perusahaan auditor yang lebih kredibel dan berpengalaman, diharapkan dapat meningkatkan transparansi dan objektifitas sehingga dapat berdampak pada kinerja perusahaan. Kepemilikan terkonsentrasi tidak berpengaruh terhadap kinerja perusahaan, menunjukkan bahwa proporsi kepemilikan pada dasarnya tidak berdampak terhadap kinerja, akan tetapi perusahaan juga dapat melakukan kebijakan terkait dengan adanya kepemilikan manajerial. Dalam penelitian ini, inovasi tidak berpengaruh terhadap kinerja perusahaan mengimplikasikan bahwa tingkat inovasi pada perusahaan makanan dan minuman cenderung baik, akan tetapi kegiatan inovasi tersebut harus ditingkatkan untuk meningkatkan keunggulan kompetitifnya sehingga dapat berdampak pada kinerja perusahaan. Selain itu, kebijakan terkait dengan struktur modal berpengaruh positif terhadap kinerja perusahaan yang mengindikasikan bahwa struktur modal yang optimal akan meningkatkan kinerja perusahaan.

Saran. Penelitian ini memiliki beberapa keterbatasan, antara lain penelitian ini hanya fokus pada perusahaan makanan dan minuman, sehingga untuk penelitian di masa yang akan datang dapat menganalisa lebih jauh pada sektor yang lain atau lingkup sektor yang lebih besar, seperti industri manufaktur. Penelitian ini terbatas pada periode tahun 2009 sampai dengan 2016, untuk penelitian yang akan datang dapat mempertimbangkan untuk menambah jumlah periode penelitian. Variabel yang diteliti terkait dengan corporate governance dapat ditambahkan mengenai kepemilikan institusional, dan kepemilikan manajerial. Juga dapat difokuskan pada pembahasan mengenai corporate governance untuk penelitian selanjutnya.

\section{DAFTAR RUJUKAN}

Arosa, B., Iturralde, T., \& Maseda, A. (2013). The Board Structure and Firm Performance in SMEs: Evidence from Spain. Investigaciones Europeas de Dirección y Economía de la Empresa 19 , 127-135.

Ramadan, Z. S., \& Ramadan, I. Z. (2015). Capital Structure and Firm's Performance of Jordanian Manufacturing Sector. International Journal of Economics and Finance; Vol. 7, No. 6, 279-284.

Theriou, N. G., Aggelidis, V., \& Theriou, G. N. (2009). A Theoretical Framework Contrasting the Resource-Based Perspective and the Knowledge-Based View. European Research Studies, Volume XII, Issue (3), 177-190. 
Aldamen, H., \& et. al. (2012). Accounting and Finance. Accounting and Finance, Vol. 52, Issue 4, 971-1000.

Atalay, M., Anafarta, N., \& Sarvan, F. (2013). The Relationship between Innovation and Firm Performance: An Empirical Evidence from Turkish Automotive Supplier Industry. Procedia - Social and Behavioral Sciences 75,226 - 235.

Barani, Z., Garkaz, M., \& Pazkad, A. (2013). Explanation of Relationship between Corporate Governance and Information Disclosure of Quoted Companies in Tehran Stock Exchange. International Journal of Academic Research in Accounting, Finance and Management Sciences, Vol.3, No.4, 33-45.

Barney, J. (1991). Firm Resources and Sustained Competitive Advantage. Journal of Management, Vol. 17, No.1, 99-120.

Bennedsen, M., Kongsted, H. C., \& Nielsen, K. M. (2008). The Causal Effect of Board Size in the Performance of Small and Medium-Sized Firms. Journal of Banking \& Finance 32, 1098-1109.

Bitler, M. P., Moskowitz, T. J., \& Jorgensen, A. V. (2006). Testing Agency Theory with Entrepreneur Effort and Wealth. The Journal of Finance Vol. LX, No. 2, 539-576.

Brigham, E. F., \& Houston. (2006). Fundamental of Financial Management: Dasar-Dasar Manajemen Keuangan. Edisi 10. Jakarta: Salemba Empat.

Bui, N. T. (2017). The Impact of Financial Leverage on Firm Performance: A Case Study of Listed Oil and Gas Companies in England. International Journal of Economics, Commerce and Management Vol. V, Issue 6, 477-485.

Ezzi, F., \& Jarboui, A. (2016). Does Innovation Strategy Affect Financial, Social and Environmental Performance? Journal of Economics, Finance and Administrative Science 21, 14-24.

Faizal, M. (2017, December 20). Industri Manufaktur Diproyeksi Serap 17 Juta Tenaga Kerja. Diambil kembali dari https://ekbis.sindonews.com: https://ekbis.sindonews.com/read/1267402/34/industri-manufaktur-diproyeksi-serap17-juta-tenaga-kerja-1513767430

Gompers, P., Ishii, J., \& Metrick, A. (2003). Corporate Governance and Equity Prices. Quarterly Journal of Economics 118 (1), 107-155.

Grosfeld, I. (2011). Ownership Concentration and Firm Performance: Evidence from An Emerging Market. PSE Working Papers .

Horváth, R., \& Spirollari, P. (2012). Do the Board of Directors' Characteristics Influence Firm's Performance? The U.S. Evidence. Prague Economic Papers, 4, 470-486.

Ilyukhin, E. (2015, April 2). The Impact of Financial Leverage on Firm Performance: Evidence from Russia. Diambil kembali dari https://papers.ssrn.com: https://papers.ssrn.com/sol3/papers.cfm?abstract_id=2589013

Jensen, M. C., \& Meckling, W. H. (1976). Theory of the Firm: Managerial Behavior, Agency Costs and Ownership Structure. Journal of Financial Economics, Vol. 3, No. $4,305-360$.

Kallamu, B. S., \& Saat, N. A. (2015). Audit Committee Attributes and Firm Performance: Evidence from Malaysian Finance Companies. Asian Review of Accounting, Vol. 23 Issue: 3, 206-231.

Karabulut, A. T. (2015). Effects of Innovation Strategy on Firm Performance: A Study Conducted on Manufacturing Firms in Turkey. Procedia - Social and Behavioral Sciences 195,1338 - 1347. 
Le , T. P., \& Phan, T. B. (2017). Capital Structure and Firm Performance: Empirical Evidence from A Small Transition Country. Research in International Business and Finance, Vol. 42, 710-726.

Lestari, D. (2018). Corporate Governance, Capital Reserve, Non-Performing Loan, and Bank Risk Taking. International Journal of Economics and Financial Issue 8 (2), 25-32.

LPEM FEB UI. (2018). Macroeconomic Analysis Series Indonesia Economic Outlook. LPEM FEB UI.

McKinsey\&Company. (2010). The Decade Ahead: Trends that Will Shape the Consumer Goods Industry. McKinsey\&Company.

Mohamed, E. K., Basuony, M. A., \& Badawi, A. A. (2013). The Impact of Corporate Governance on Firm Performance in Egyptian Listed Companies. Corporate Ownership \& Control, Volume 11, Issue 1.

Molnar, M., Chen, W., \& Wang, B. (2017). Corporate Governance and Firm Performance in China. OECD Economics Department Working Papers No. 1421.

Namazi, M. (2013). Role of the Agency Theory in Implementing Management's Control. Journal of Accounting and Taxation Vol. 5, No. 2, 38-47.

Nguyen, T., Locke, S., \& Reddy, K. (2015). Ownership Concentration and Corporate Performance from a Dynamic Perspective: Does National Governance Quality Matter? International Review of Financial Analysis, 41, 148-161.

OECD. (2015). Corporate Governance: Promoting Sound Corporate Governance Practices. OECD.

Ogebe, P., Ogebe, J., \& Alewi, K. (2013). The Impact of Capital Structure on Firms' Performance in Nigeria. MPRA Paper No. 46173.

Salim, M., \& Yadav, R. (2012). Capital Structure and Firm Performance: Evidence from Malaysian Listed Companies. Procedia - Social and Behavioral Sciences 65 , 156166.

SBM BINUS. (2017, November 22). Fast Moving Consumer Goods (FMCG). Diambil kembali dari https://sbm.binus.ac.id: https://sbm.binus.ac.id/2017/11/22/fast-movingconsumer-goods-fmgc/

Shamsabadi, H., Min, B., \& Chung, R. (2016). Corporate Governance and Dividend Strategy: Lessons from Australia. International Journal of Managerial Finance, Vol. 12, Issue:5, 583-610.

Sueyoshi, T., Goto, M., \& Omi, Y. (2010). Corporate Governance and Firm Performance: Evidence from Japanese Manufacturing Industries After the Lost Decade. European Journal of Operational Research, Vol. 203, Issue 3 , 724-736.

Therrien, P., Doloreux, D., \& Chamberlin, T. (2011). Innovation Novelty and (Commercial) Performance in the Service Sector: A Canadian Firm-Level Analysis. Technovation, (31), 655-665.

Tuan, N., \& et. al. (2016). The Effects of Innovation on Firm Performance of Supporting Industries in Hanoi - Vietnam. Journal of Industrial Engineering and Management 9 (2), 413-431.

Vyas, V. (2009). Innovation and New Product Development by SMEs: An Investigation of Scottish Food and Drinks Inudstry. Doctoral Dissertation, Edinburgh Napier University. 
Wade, M., \& Hulland, J. (2004). Review: The Resource-Based View and Information Systems Research: Review, Extension, and Sugestions for Future Research. MIS Quarterly Vol. 28 No. 1.

Widianto, S. (2017, October 24). Pertumbuhan Industri Counsumer Goods Indonesia Tertinggi di Asia Tenggara. Diambil kembali dari http://www.pikiran-rakyat.com: http://www.pikiran-rakyat.com/ekonomi/2017/10/24/pertumbuhan-industricounsumer-goods-indonesia-tertinggi-di-asia-tenggara-412196

Yasmin, P. A. (2018, April 23). Menperin: Industri Makanan dan Minuman Tumbuh 9,23\%. Diambil kembali dari https://finance.detik.com: https://finance.detik.com/industri/d-3985814/menperin-industri-makanan-danminuman-tumbuh-923 